\title{
Rafał Cekiera
}

Uniwersytet Śląski w Katowicach

(D) https://orcid.org/0000-0003-3649-6645

\section{Aktywność zawodowa i jej bariery w opinii osób z chorobami reumatycznymi}

\begin{abstract}
The article discusses the level of professional activity of people with rheumatic diseases and attempts to identify the most important they encounter. The analyses are based on a survey encompassing 338 respondents. The survey was conducted as part of a research project carried out in 2017 dedicated to the socio-professional circumstances of patients dealing with rheumatic diseases. The article shows a point of view of the group of people with illness who experienced health problems and complications firsthand. However, this issue is important not only for them, but has broad social repercussions relating to the labour market and overall functioning of social policies.
\end{abstract}

Key words: professional activity, work, rheumatic diseases, professional marginalization, people with chronical illnesses

Sytuacja osób cierpiących na choroby reumatyczne jest problemem wymagającym poważnego namysłu opartego na rzetelnych badaniach. Specyfika tego typu schorzeń powoduje, że jest to zagadnienie o szerokim społecznym znaczeniu i wielorakich potencjalnych reperkusjach. Jedną z kluczowych kwestii — zarówno dla chorych, jak i z punktu widzenia całego społeczeństwa - jest kwestia aktywności osób dotkniętych takimi chorobami na rynku pracy, w tym sposobów ich aktywizacji i możliwości zapewnienia warunków zatrudnienia pozwalających na łączenie pracy z chorobą.

Choroby reumatyczne - wbrew stereotypowi - dotyczą również osób młodych, które kształcą się bądź rozpoczynają okres aktywności zawodowej. Funkcjonuje czasem fałszywe przekonanie, że tzw. reumatyzm to po prostu zwyrodnieniowe zmiany stawów, które dotykają wyłącznie osób w podeszłym wieku. Tymczasem zapalne choroby tkanki łącznej często pojawiają się w okresie drugiej czy trzeciej 
dekady życia, a czasem nawet już w okresie dzieciństwa. Charakter tego typu schorzeń bywa bardzo dokuczliwy, łączy się z wieloma niezwykle uciążliwymi objawami i miewa ciężki przebieg, niekiedy zagrażający życiu. Choroby tego typu wymagają długotrwałego, bardzo agresywnego leczenia - w tym również leków stosowanych $\mathrm{w}$ chemioterapii nowotworów. Choroby układowe tkanki łącznej obejmują procesem chorobowym liczne narządy i układy w organizmie, co wiąże się z koniecznością wielospecjalistycznego leczenia. Przewlekły i nieuleczalny charakter owych schorzeń sprawia, że proces leczenia wpisany jest na stałe w życie osoby dotkniętej chorobą reumatyczną (Kwiatkowska i in., 2014).

Niestety, częstym następstwem postępującej choroby bądź skutkiem ubocznym niejednokrotnie trudnego i uciążliwego procesu leczenia jest konfrontacja z przejściem na rentę bądź utratą pracy w bardzo młodym wieku. Dla sporej części chorych reumatycznie - szczególnie osób młodych, dobrze wykształconych, ambitnych i mających własne wizje kariery zawodowej - choroba stanowi poważny problem, który niweczy życiowe i zawodowe plany bądź wymusza ich radykalną modyfikację.

Przewlekły ból, trudności w wykonywaniu codziennych czynności, częste wizyty u lekarzy specjalistów oraz pobyty na oddziałach szpitalnych to tylko nieliczne z utrudnień, które w swoim życiu muszą uwzględnić pacjenci. W pracy spotykają ich często problemy ze względu na ograniczoną dyspozycyjność czy wynikającą z choroby mniejszą wydajność. Część chorych nie będąc w stanie sprostać wymaganiom pracodawców opuszcza rynek pracy. Utrata pracy grozi z kolei nie tylko załamaniem w sferze ekonomicznej, ale też często kryzysem natury psychicznej, który utrudnia prawidłowy proces leczenia. $\mathrm{W}$ wielu analizach podkreśla się psychospołeczne konsekwencje chorób reumatycznych: „Zatrważające jest, że po 10 latach choroby czynnych zawodowo jest tylko $20 \%$ chorych, największe zagrożenie występuje już w pierwszym roku trwania choroby" (Tłustochowicz, 2014, s. 166).

W niniejszym artykule omówiony zostanie fragment wyników badań uzyskanych w trakcie realizacji projektu „Aktywność zawodowa osób z chorobami reumatologicznymi", który prowadzony był w zespole kierowanym przez autora artykułu w okresie od kwietnia do listopada 2017 roku na zlecenie Ogólnopolskiego Stowarzyszenia Młodych z Zapalnymi Chorobami Tkanki Łącznej „3majmy się razem". Przeprowadzone badania miały na celu identyfikację poziomu aktywności społeczno-zawodowej osób z chorobami reumatycznymi oraz rozpoznanie najważniejszych barier, które ją utrudniają.

\section{Założenia metodologiczne}

Naczelnym imperatywem przyświecającym podjęciu badania było poznanie opinii osób, które zmagają się z doświadczeniem choroby reumatycznej, na temat 
ich aktywności zawodowej i odczuwanych barier w podejmowaniu zatrudnienia. Nawet najlepsze w teorii rozwiązania wymagają ewaluacji na podstawie analizy ich praktycznej realizacji i faktycznych korzyści dla ich odbiorców. Najbardziej autentycznymi ekspertami uwarunkowań funkcjonowania na rynku pracy są osoby dotknięte chorobą, których wiedza nie jest w żaden sposób zapośredniczona, lecz wynika z autopsji. Wypowiedzi samych chorych stanowią zasadniczy materiał analiz.

Referowane w artykule wyniki badań zostały uzyskane za pomocą kwestionariusza ankiety, dostępnego w okresie od 1 czerwca do 1 października 2017 roku na portalu eBadania.pl. Narzędzie badawcze składało się z 34 pytań, wśród których znalazły się także pytania otwarte. Jego przygotowanie poprzedziła kwerenda badawcza, polegająca na analizie danych zastanych — różnych publikowanych w ostatnim czasie materiałów, które zawierały treści dotyczące analizowanej tematyki. Pozwoliło to wyznaczyć podstawowe obszary problemowe i w ich ramach sformułować konkretne pytania kwestionariusza ankiety. Ważnym jego elementem były pytania otwarte - ich obecność uzasadniona była chęcią oddania respondentom miejsca na swobodne wypowiedzi, nieukierunkowane w żaden sposób przez suflowane podpowiedzi. Wśród stawianych pytań badawczych w ramach projektu znalazły się między innymi następujące:

Jakie największe problemy Pani/Pana zdaniem tacza się z chorobą?

Co Pani/Pana zdaniem najbardziej utrudnia cierpiacym na choroby reumatyczne podejmowanie pracy zawodowej?

Co Pani/Pana zdaniem powinno się zrobić, aby ułatwić cierpiacym na choroby reumatyczne funkcjonowanie na rynku pracy?

Wybór kwestionariusza ankiety jako narzędzia badawczego miał na celu zebranie jak największej liczby odpowiedzi - co zwiększało szansę na rzetelność badań i wiarygodność uzyskanych wyników. Link do kwestionariusza kolportowany był za pośrednictwem stron internetowych i różnych fanpage’y grupujących osoby zmagające się z chorobami reumatycznymi - przede wszystkim kilkukrotnie zamieszczano link z zaproszeniem do badania na fanpage'u Ogólnopolskiego Stowarzyszenia Młodych z Zapalnymi Chorobami Tkanki Łącznej „3majmy się razem" (zob. np. posty z 12 i 7 września, 18 sierpnia, 13 lipca, 27 czerwca) ${ }^{1}$.

Ankietę wypełniło 338 respondentów, co należy uznać za dużą liczbę, gwarantującą wielość perspektyw i spojrzeń na problem oraz niski wskaźnik ryzyka anegdotyczności, czyli nadmiernej ekspozycji i nieuprawnionej ekstrapolacji osiągniętego wyniku w małej grupie na szersze zbiorowości. Szczegółowa charakterystyka badanej grupy znajduje się w dalszej części raportu. 


\section{Charakterystyka badanej grupy}

Wśród osób biorących udział w badaniu zdecydowaną większość — aż 88,76\% (równe 300 osób) - stanowiły kobiety, odsetek mężczyzn w badaniu wyniósł 11,24\% (38 osób). Taki rozkład wynikać może z kilku czynników. Pierwszym z nich jest większa częstotliwości zapadania kobiet na niektóre z chorób, przede wszystkim na reumatoidalne zapalenie stawów (RZS) i toczeń rumieniowaty układowy (TRU) (Smoleńska, Zdrojewski, 2010) - a wśród respondentów cierpiący na te schorzenia stanowili niemal połowę próby. Można także przyjąć większą gotowość do wzięcia udziału w ankiecie ze strony kobiet niż mężczyzn, co stanowi pewne ograniczenie uzyskanych wyników.

Badana grupa była znacząco zróżnicowana w kwestii wieku respondentów. Najliczniej reprezentowane były osoby będące w czwartej dekadzie życia - ankietę wypełniły 122 osoby pomiędzy 31. a 40. rokiem życia, co stanowiło $36,09 \%$ całej próby. Drugą w kolejności liczby reprezentantów była kategoria wiekowa $21-30$ lat ( 96 osób - 28,40\% badanych), a następnie 41-50 lat (67 osób - 19,82\%). Duże zróżnicowanie wieku (zob. wykres 1) respondentów jest istotną przesłanką zwiększającą poziom rzetelności uzyskanych rezultatów.

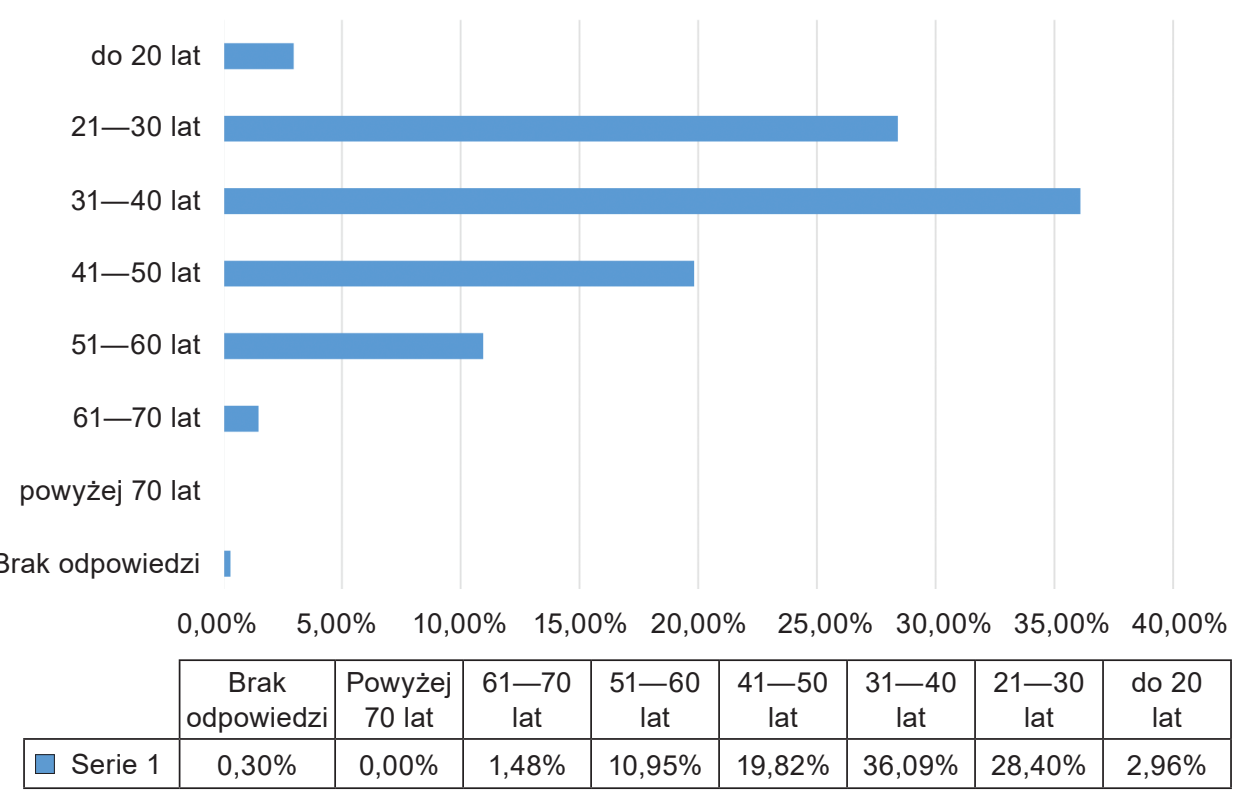

Wykres 1. Wiek respondentów $(\mathrm{n}=338)$

Z podobnym rozwarstwieniem badanej grupy mamy do czynienia w przypadku deklarowanego miejsca zamieszkania. Badani pochodzili z miejscowości o różnej wielkości — co w przypadku analiz aktywności zawodowej ma znaczenie, gdyż 
może różnicować doświadczenia związane z dostępem do rynku pracy i potrzebami tego rynku w najbliższej okolicy (zob. wykres 2).

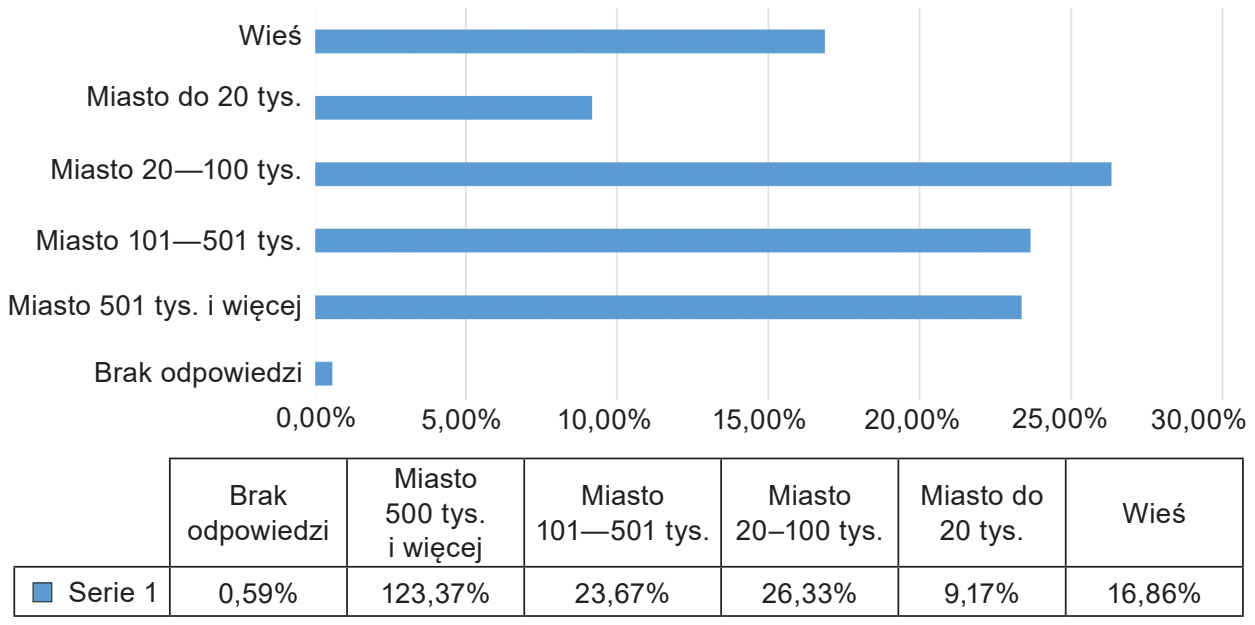

Wykres 2. Miejsce zamieszkania respondentów $(n=338)$

Jeśli chodzi o poziom wykształcenia badanych — inaczej niż w całej populacji mieszkańców Polski — wśród respondentów przeważały osoby z wykształceniem wyższym (202 osoby - 59,76\%). Średnim wykształceniem legitymowało się 113 osób (33,43\% badanych), zasadniczym zawodowym 14 osób (4,14\%), zaś gimnazjalnym bądź podstawowym zaledwie 6 osób (1,78\%).

W kontekście tematu badania za ważne uznano ewentualne posiadanie przez respondentów orzeczenia o stopniu niepełnosprawności. Większość ankietowanych $(57,10 \%)$ nie miała takiego orzeczenia. Wśród osób, które je uzyskały, przeważają posiadacze orzeczenia o umiarkowanym stopniu niepełnosprawności $(24,26 \%$ całej próby), w dalszej kolejności o lekkim stopniu niepełnosprawności (11,24\%), najmniejszy odsetek stanowią natomiast osoby o znacznym stopniu niepełnosprawności $(5,62 \%)$.

Badaną grupę mocno zróżnicuje także czas, który minął od momentu zdiagnozowania choroby. Największy odsetek respondentów stanowią osoby, u których chorobę wykryto w przedziale od roku do 5 lat wcześniej (34,02\% - 115 osób), a następnie osoby z długotrwałą historią choroby — powyżej 10 lat $(27,22 \%$ — 92 badanych). Uzyskany rozkład deklaracji (wykres 3) zwiększa wiarygodność badania i stwarza szansę na rozpoznanie szerokiej gamy problemów łączących się z barierami w aktywności osób chorych. Zróżnicowanie długości borykania się z chorobą zapewnia dostęp do rozmaitych doświadczeń i perspektyw chorych w postrzeganiu schorzenia i jego wpływu na ich aktywność.

Uczestników badania ankietowego poproszono o podanie informacji na temat schorzenia, na które cierpią. Największa część badanych choruje na reumatoidalne zapalenie stawów (RZS) — w sumie w ankiecie wzięło udział 110 takich osób (32,54\% wszystkich respondentów). RZS jest układową, autoimmunologiczną 


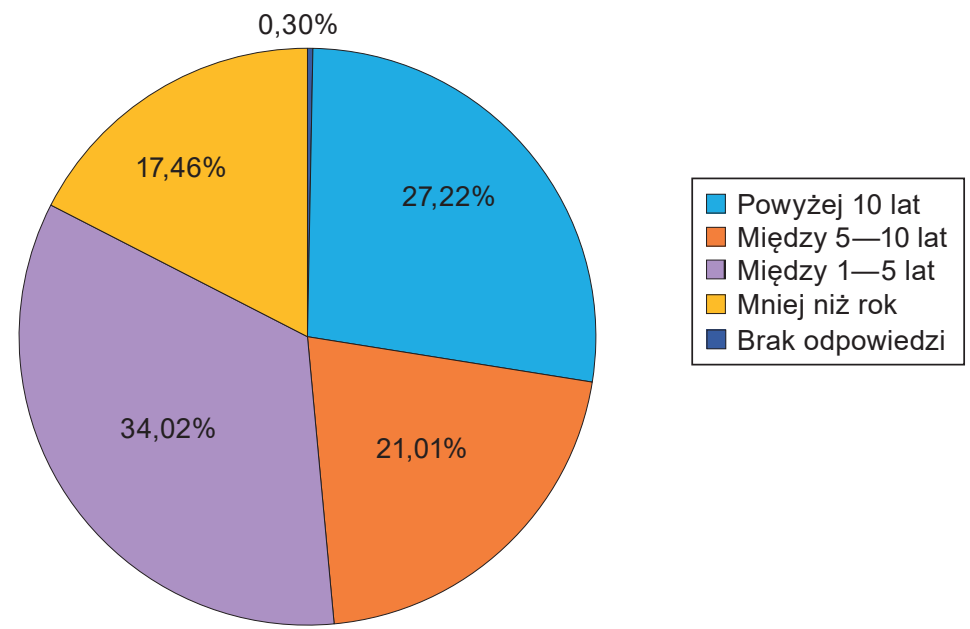

Wykres 3. Okres, jaki upłynął od momentu zdiagnozowania choroby u respondentów $(n=338)$

chorobą o podłożu zapalnym i nieznanej etiologii. Chorobę cechuje postępujący charakter, który prowadzić może do destrukcji stawów, zajęcia narządów wewnętrznych, niepełnosprawności, inwalidztwa i przedwczesnej śmierci. W opisach schorzenia zwraca się też uwagę na często wynikające z niego utrudnione funkcjonowanie w społeczeństwie, pogorszenie dobrostanu psychicznego oraz obniżenie jakości życia. Dla pacjentów problemem bywa także koszt leczenia oraz różne związane z jego podjęciem następstwa (Wisłows ka i in., 2010).

Wśród ankietowanych 48 osób (14,20\%) cierpi na zesztywniające zapalenie stawów kręgosłupa (ZZSK). Jest to zapalna choroba przewlekła o nie do końca poznanej przyczynie. Schorzenie dotyczy 0,15-0,5\% populacji — na 1000 osób choruje 15-50. Szacuje się, że w Polsce na ZZSK cierpi ok. 50000 chorych (Stanisławska-Biernat, 2015). Proces chorobowy wywołuje ból i sztywność (szczególnie w dolnym odcinku kręgosłupa), prowadząc do ograniczenia ruchomości i częściowego czy wręcz całkowitego zesztywnienia zajętych stawów, głównie kręgosłupa (Wiland, 2012). Ocenia się, że u 1/3 chorych przebieg ZZSK jest ciężki i prowadzi do znacznej utraty sprawności (Kołczewska, 2004).

Trzecią w kolejności z chorób respondentów jest toczeń rumieniowaty układowy (TRU), który został zaznaczony przez 40 badanych (11,83\% respondentów). Jest to choroba o podłożu autoimmunologicznym, charakteryzująca się różnorodnym obrazem klinicznym oraz niepewnym rokowaniem. Jej przebieg może być łagodny (z okresami zaostrzeń i remisji) lub gwałtowny, prowadzący do postępującego i zagrażającego życiu uszkodzenia poszczególnych narządów (Idasiak-Piechocka, Perkowska-Ptasińska, 2016). Toczeń początkowo traktowany był jako choroba dermatologiczna — badania jednak szybko potwierdziły, że to choroba wielonarządowa o skomplikowanym i często niejednoznacznym, zindywidualizowanym przebiegu. Rodziło to i nadal powoduje problemy z identyfikowaniem, diagnozowaniem i klasyfikowaniem tej jednostki chorobowej. Kryteria diagnostyczne na przestrzeni ostatnich 40 lat zmieniały 
się wraz z pojawianiem się nowych narzędzi i poszerzaniem wiedzy na temat patomechanizmów schorzenia (Daca, Bryl, 2013). Najczęściej chorują na toczeń kobiety w wieku rozrodczym, co przyczynia się do wielu problemów zdrowotnych związanych z ciążą i porodem. Stosunek chorych kobiet do mężczyzn wynosi 9:1 (Szczepańska i in., 2008).

Ostatnią większą grupę respondentów stanowiły osoby cierpiące na fibromialgię (32 osoby - 9,47\%). Schorzenie to jest przewlekłym, uogólnionym zespołem bólowym występującym wraz z uczuciem znacznego zmęczenia i subiektywnymi objawami patologii w narządzie ruchu. To jednostka chorobowa mająca relatywnie niedługą historię - kryteria diagnostyczne dla fibromialgii ogłosiło American College of Rheumatology w 1990 roku, zaś jako odrębny zespół fibromialgia została wydzielona już w 1987 roku przez American Medical Association. Wśród naukowców ciągle trwa dyskusja nad tym, czym jest fibromialgia i jak ją diagnozować (Wytrążek i in., 2009). Pozostałe jednostki chorobowe reprezentowane były wśród respondentów w mniejszej częstotliwości. Szczegółowy rozkład został zamieszczony w tabeli 1 .

Tabela 1

Rozkład procentowy chorób respondentów $(\mathrm{n}=338)$

\begin{tabular}{|l|c|}
\hline \multicolumn{1}{|c|}{ Jednostka chorobowa } & Odsetek badanych (\%) \\
\hline Reumatoidalne zapalenie stawów (RZS) & 32,54 \\
\hline Zesztywniające zapalenie stawów kręgosłupa (ZZSK) & 14,20 \\
\hline Toczeń rumieniowaty układowy (TRU) & 11,83 \\
\hline Fibromialgia & 9,47 \\
\hline Młodzieńcze idiopatyczne zapalenie stawów (MIZS) & 5,33 \\
\hline Łuszczycowe zapalenie stawów (ŁZS) & 4,73 \\
\hline Twardzina układowa & 4,73 \\
\hline Mieszana choroba tkanki łącznej & 2,66 \\
\hline Choroba zwyrodnieniowa stawów & 1,78 \\
\hline Spondyloartropatia seronegatywna & 1,48 \\
\hline Choroba Stilla & 1,18 \\
\hline Zespół Sjögrena & 0,59 \\
\hline Zapalenie skórno-mięśniowe & 0,30 \\
\hline Układowe zapalenia naczyń & 0,30 \\
\hline Inne/brak odpowiedzi & 7,69 \\
\hline
\end{tabular}




\section{Poziom aktywności zawodowej badanych i jej uwarunkowania}

Aktywność zawodową zdefiniować możemy jako „wykonywanie pracy w zamian za wynagrodzenie lub inną formę środków utrzymania lub gotowość do jej wykonywania" (Garbat, 2013, s. 33). Praca ma dla osoby chorej znaczenie wielorakie, dalece wykraczające poza aspekt związany wyłącznie z zapewnieniem potrzebnych do codziennej egzystencji środków. Stanowi jeden z zasadniczych wyznaczników odczuwanej jakości życia. W przypadku osób chorych zwraca się także uwagę na terapeutyczne znaczenie zatrudnienia (Kubicka, 2012, s. 84). Jak podkreśla Marcin Garbat, aktywność zawodowa stanowi najlepszą drogę do integracji społecznej: „Praca zawodowa stanowi czynnik przeciwdziałający izolacji i wykluczeniu społecznemu, tj. zjawiskom sprzecznym z prawidłowym rozwojem i działaniem w zespole" (Garbat, 2013, s. 10). Zwraca na ten aspekt uwagę również Roman Ossowski: „Praca jest wartością, która umożliwia jednostce pełne uczestnictwo w życiu społecznym. Zapewnia jej materialne warunki egzystencji, określa rolę i status $w$ ramach organizacji społecznej. Należy podkreślić, że praca oprócz funkcji ekonomicznej spełnia też wiele innych — jest warunkiem, okazją lub sposobem realizacji wielu potrzeb pozaekonomicznych. Coraz częściej w przypadku choroby i niepełnosprawności dostrzega się znaczenie pracy jako elementu rehabilitacji społecznej" (1991, s. 321). W uzyskanych odpowiedziach respondentów dobitnie podkreślano pozamaterialne wymiary aktywności zawodowej, co potwierdza konstatację, że praca jest nie tylko „formą społecznego współbycia” (Sulima, 2015), lecz również „olejem namaszczającym godnością” (Bergoglio, Skórka, 2013, s. 185).

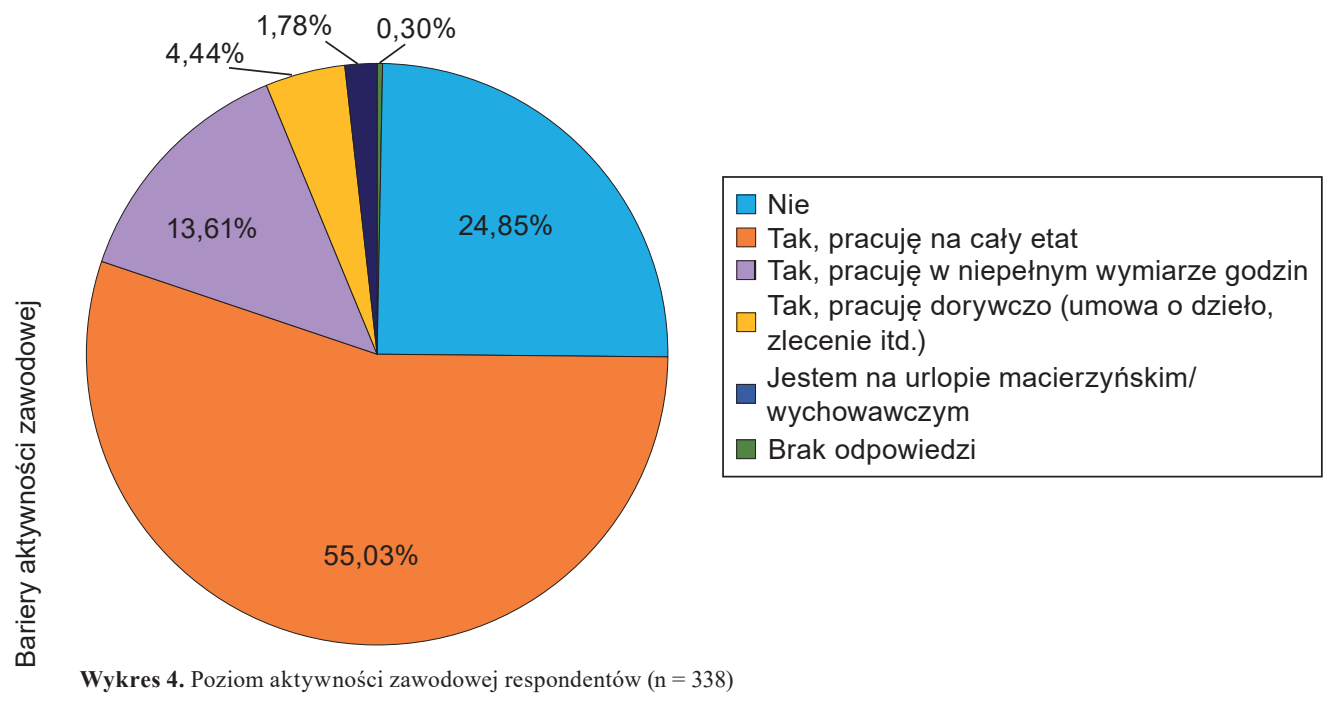


$60,00 \%$

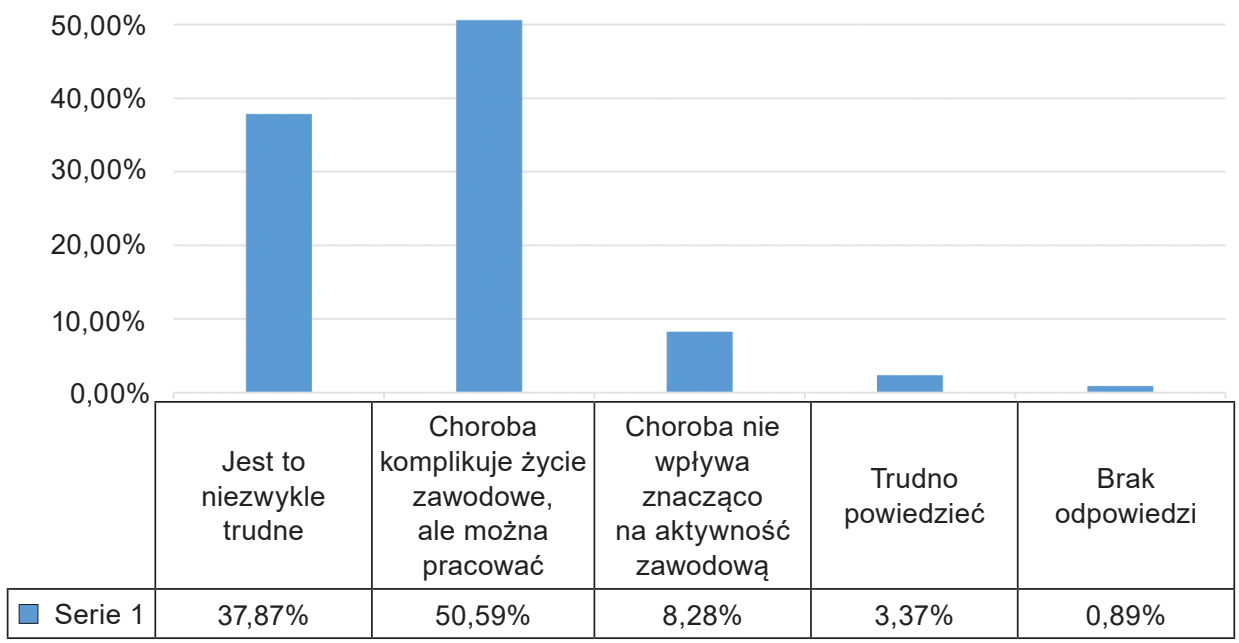

Wykres 5. Ocena możliwości łączenia aktywności zawodowej z chorobą i leczeniem

W badanej grupie większość stanowiły osoby aktywne zawodowo. Zatrudnienie na pełny etat zadeklarowało 55,03\% (186 osób), w niepełnym wymiarze pracuje 13,61\% (46 respondentów), zaś pracę dorywczą na podstawie umowy o dzieło czy zlecenia wykonuje 4,44\% (15 osób). Odsetek osób wykonujących pracę w mniejszym lub większym wymiarze wyniósł w badaniu w sumie 73,08\% (wykres 4). Z odpowiedzi na pytania otwarte wyłania się obraz niejednokrotnie olbrzymiej determinacji, dzięki której możliwe jest podejmowanie aktywności zawodowej przez chorych. Przykładem może być wpis osoby, która ma poczucie, że ze wszystkimi problemami, które w związku z chorobą na nią spadły, musi sobie radzić sama - bez wsparcia jakichkolwiek instytucji pomocowych:

Brak samodzielności, depresja, zmęczenie i brak wsparcia ze strony stużby zdrowia i państwa. Musze pracować jak zdrowy czlowiek na peten etat, żeby się utrzymać, i kosztuje mnie to bardzo dużo zdrowia i energii.

Respondentów zapytano o ich ocenę możliwości łączenia aktywności zawodowej z chorobą i leczeniem. Zaledwie 8,28\% badanych (28 osób) stwierdziło, że choroba nie ma znaczącego wpływu na aktywność zawodową (wykres 5). Wynik ten dobitnie wskazuje na skalę problemu, uwidaczniając to, jak wielu chorych musi zmagać się z różnorodnymi trudnościami, aby móc podejmować pracę zawodową. Pozytywnym przykładem skutecznego i relatywnie łatwego godzenia pracy zawodowej z chorobą może być następująca wypowiedź:

Ja nie mam z tym problemu, bo mam wyższe wykształcenie $i$ stosunkowo lekka prace, która moge wykonywać przy moich schorzeniach. 
Ponad połowa badanych — 50,59\% (171 osób) — uznała, że choroba komplikuje życie zawodowe, ale nie uniemożliwia podjęcia pracy:

Ja od samego poczatku pracuję w zawodzie nauczyciela i przy przychylnym spojrzeniu dyrektora szkoty godzę leczenie i pracę.

Dla wielu badanych jednak znalezienie takiego zatrudnienia, które nie kolidowałoby z procesem leczenia czy ewentualnymi atakami choroby, jest jednym z kluczowych wyzwań:

[Największy problem łączący się z chorobą stanowi] obecnie znalezienie pracy dostosowanej do dość częstych wizyt w szpitalu.

Utrudnienie w podjęciu pracy $i$ w ogóle ze znalezieniem takiej, w której bytyby szanowane pobyty $w$ szpitalu.

Niektórzy relacjonują swoistą całożyciową mediację z chorobą - czyli uwzględnianie kontekstu bycia człowiekiem chorym od początku drogi zawodowej, jeszcze w okresie wyboru ścieżki kariery:

Podstawa jest rodzaj wykonywanej pracy i poziomu schorzenia. W moim przypadku, jak 30 lat temu zaczęly się problemy, poszedtem w kierunku rozwoju umystowego. Ukończyłem trzy kierunki studiów i nie mam większego problemu z realizowaniem się zawodowym.

Ja choruję od dziecka, więc zawsze walczyłam o szkotę, a teraz pracę.

Za „niezwykle trudne” łączenie pracy zawodowej z chorobą i leczeniem uznało aż 37,87\% respondentów (128 osób). Skalę i zasięg tych trudności charakteryzować może wpis jednego $z$ badanych:

Większość stanowisk pracy wymaga od pracownika dużego wysiłku fizycznego lub 8-godzinnego siedzenia przy biurku. W moim wypadku obie prace sprawiaja u mnie ogromne pogorszenie choroby.

Wśród wypowiedzi badanych znalazły się także niezwykle gorzkie konstatacje, pełne rezygnacji opartej na własnych wcześniejszych doświadczeniach:

Nic się nie da zrobić. Przez pierwsze 2 lata choroby pracowatam i z biegiem czasu, gdy sil zaczynato brakować, widziałam niezadowolona minę pracodawcy $i$ w końcu powiedziat, że powinnam zrezygnować z pracy, bo jestem niewydajna. Samo życie.

Zdarzało się w badaniu, że trudności były opisywane bardzo konkretnie - co daje wgląd w codzienność pracującej osoby chorej:

Z racji tego, że pracuję $w$ telemarketingu, zdecydowanie utrudnia mi suchość w jamie ustnej oraz suchość oczu. Pomimo przyjmowania wszelkiego rodzaju 
nawilizaczy ulga jest tylko chwilowa. Wieczne problem z gardtem, ból gardła, chrypka.

Sygnalizowane przez respondentów trudności związane z łączeniem pracy z chorobą i leczeniem odnoszą się do wielu porządków. Pierwszą i fundamentalną barierę stanowią fizyczne dolegliwości, będące następstwem choroby - ograniczenia sprawności czy trudny do uśmierzenia, przewlekły ból. Był on przywoływany jako ogólna kategoria, a także odnoszony do konkretnych części ciała:

Ból 24 godziny na dobę, opuchnięcie rąk i kolan, sztywność stawów, jakby niedowład nóg.

Ciagłe bóle wszystkich stawów, kończyn dolnych, górnych i kręgostupa.

Niezwykle często podkreślano jego totalny, paraliżujący charakter, wyniszczający psychicznie i powodujący poważne komplikacje w społecznej aktywności:

Ból, który uniemożliwia w zasadzie wszystko. Zmęczenie, które jest, a nie ma powodu, żeby było. Brak pracy, gdyż ból i zmęczenie nie pozwalają na jej podjecie.

Ból utrudniający codzienne funkcjonowanie. Odbierający radość życia.

Uciążliwość i dolegliwość cierpienia fizycznego podkreślana była czasem już w samej formie zapisu — przez powtarzanie tego samego słowa próbowano oddać dokuczliwość cierpienia („,ogólne zmęczenie i ból, ból, ból”) czy relacjonowano je stosując dobitne, kategoryczne stwierdzenia — „Ból, na który żaden lek nie działa”. Wielokrotnie w wypowiedziach badanych przywoływano ten obszar, zwracając uwagę, w jak wielkim stopniu dezorganizuje on dzień pracy, utrudnia czy czasem wręcz uniemożliwia funkcjonowanie w ramach rygorów zawodowych:

Niemożność wykonywania wielu rzeczy, podstawowych. Gdy RZS zaatakuje dłonie, to co można robić? Ból uniemożliwia nawet podniesienie czegoś, zwykty chwyt, nawet stukanie w klawiature jest cholernie bolesne.

Myślę, że największym wrogiem w tej sytuacji jest chroniczny ból, który potrafi wszystko skomplikować i utrudnić.

Ogromny ból dezorganizujący życie prywatne i służbowe.

Dla wielu chorych niezwykle uciążliwym balastem jest kompleksowość doświadczanych dolegliwości:

Codzienny ból kręgostupa, bioder i kolan, sztywność stawów, zapalenia stawów, objaw Raynauda, migreny, osłabienie, podatność na infekcje i trudne ich leczenie, ogromne klopoty ze wzrokiem. Wszystko to razem w jednym ciele powoduje spory bagaż fizyczny [...]. 
W wypowiedziach zdarzają się odniesienia do wielu różnych aktywności zawodowych, których podejmowanie staje się w obliczu choroby trudnym czy wręcz niemożliwym do podjęcia wyzwaniem:

Mam gospodarstwo rolne $i$ w moim przypadku uszkodzone stawy dloni i stóp spowodowaty zakaz wykonywania pracy.

[...] trudno dobrać rodzaj pracy — fizyczna: odpada, ale praca „,za biurkiem” też jest trudna, sa dni, gdy ciężko pisać na klawiaturze, operować myszka, utrzymać $w$ dtoniach przedmioty biurowe, np. zszywacz... Ból i obrzęk ograniczaja możliwości wyboru wykonywanej pracy.

Wielokrotnie podkreślano zarówno nieprzewidywalność ataków bólu, jak i jego dojmujący charakter, który niejednokrotnie paraliżuje i uniemożliwia określane przez respondentów jako „,normalne” funkcjonowanie:

Okropny ból i podczas nawrotu choroby brak możliwości normalnego życia.

Podczas silnego bólu stawów lub kręgostupa nie jestem w stanie normalnie funkcjonować i potrzebuje wtedy wolnego dnia od pracy.

Ból, obrzęki i sztywność dużych stawów uniemożliwiajace normalne funkcjonowanie - nie mogę zgiać kolan, kucnać, klęknać, o wejściu i wyjściu z wanny nie ma mowy. Stawy sq dodatkowo rozgrzane, większość rodzajów ruchu wywotuje w nich ból [...].

W wypowiedziach respondenci zwracali też uwagę na ograniczenia ruchowe, takie jak silne bóle kolan przy dłuższym chodzeniu - czy po prostu problemy ze swobodnym poruszaniem się, co także wpływa na zdolność do podejmowania aktywności zawodowej:

Ograniczenie ruchowe, które uniemożliwia wykonywanie podstawowych czynności życiowych.

[...] chodzenie, jakbym była w podeszłym wieku.

Konsekwencją tych ograniczeń może być mniejsza mobilność osób chorych w wielorakim sensie: zarówno przemieszczania się w miejscu pracy, jak i możliwości dojazdu do pracy. Problem ten był często podnoszony przez badanych.

Uciążliwe dla chorego i w jego zawodowym funkcjonowaniu są także następstwa walki z chorobą - czego przykładem mogą być skutki uboczne chemioterapii, takie jak boleści, mdłości, osłabienie czy depresja:

Ból wszystkiego (stawy, mięśnie, głowa itd.). Złe samopoczucie, np. po chemioterapii. Depresja.

Mniej fizycznie uciążliwą, lecz także znacząco utrudniającą pacjentom zawodowe funkcjonowanie dolegliwością wynikającą z choroby jest zmęczenie, mające 
chroniczny i uciążliwy charakter. Niejednokrotnie powoduje ono - na co zwraca uwagę jedna $\mathrm{z}$ badanych — niemoc, doprowadzając w danym okresie do stanu zwykłej wegetacji:

Tracenie sprawności i czasami niemoc, by ten proces zahamować. Podczas agresji choroby bardzo duże zmęczenie, $w$ wyniku czego praca $i$ życie jest zbyt męczace. Jest to okres wegetacji.

Mocne ZMĘCZENIE wpływające na jakość i ilość pracy. Często nie mogę pracować, ponieważ czuję się niesamowicie zmęczona. Nieadekwatnie do tego, co robiłam. Drugi aspekt — ból stawów dłoni. Gdy więcej, intensywniej pracujęwszystkie się ,zapalaja”, puchna.

Kolejnym niezwykle często przywoływanym przez ankietowanych utrudnieniem w podejmowaniu aktywności zawodowej jest cechująca choroby reumatyczne ich nieprzewidywalność oraz będący następstwem tego brak pełnej dyspozycyjności pracownika. Specyfika chorób, z którymi zmagają się respondenci, łączy się z dużą dozą niepewności dotyczącej okresu ataku choroby i nasilenia się jej objawów. Wielokrotnie podkreślali to badani, wskazując na wynikające z tej cechy niedogodności:

To sa choroby nieobliczalne, można być dzisiaj super wydajnym pracownikiem, a jutro zniknąć na dlugi czas...

[...] utrudnieniem jest to, że nie wiadomo, kiedy pogorszy się stan zdrowia. U mnie z dnia na dzień przestałam ruszać prawym nadgarstkiem, ból był nie do zniesienia. Problemem było to, że jestem praworęczna, bezsilność doprowadza mnie do płaczu.

Życie osoby chorej ma często charakter nieciągły — okresy dobrego samopoczucia i bardzo dobrej kondycji fizycznej przeplatają się z występującymi w nieregularnych i niemożliwych do przewidzenia okresach stanami niemocy, bólu i w konsekwencji — niemożności pracy.

Nieprzewidywalna dyspozycja — raz się dobrze czujesz i możesz dobrze $i$ wydajniej pracować, a innego dnia nie jesteś w stanie dotrzeć do pracy. Też bardzo częste wizyty i badania, hospitalizacje, operacje, rehabilitacja powoduja dość częstą absencję w pracy.

Taka sytuacja wyklucza pełną dyspozycyjność i wymaga takich warunków pracy i podejścia ze strony pracodawcy, które umożliwiałoby choremu wolne dni w czasie niedyspozycji oraz wizyty w rozmaitych przychodniach lekarskich z trudną do oszacowania regularnością. Wiele osób wskazuje właśnie problem niedyspozycyjności jako istotną barierę w podejmowaniu zawodowej aktywności:

Brak dyspozycyjności (z uwagi na fakt częstych pobytów w szpitalach, placówkach medycznych oraz złe samopoczucie) wyklucza z rynku pracy osobę przewlekle chora, która chciałaby podjąć pracę stata. 
Respondenci wskazują na trudności w relacji: cierpiący na chorobę reumatyczną pracownik - pracodawca, wynikające z niedyspozycyjności. Pracodawcy mają często trudność $\mathrm{z}$ akceptacją specyficznych uwarunkowań funkcjonowania chorego. W odpowiedziach respondentów uwidacznia się brak zrozumienia i niechęć pracodawców do indywidualnego, elastycznego podejścia do zawodowego funkcjonowania osoby chorej. Respondenci odczuwali, że są postrzegani jako pracownicy drugiej kategorii, mniej wartościowi, których sytuacja nie jest przez pracodawców rozumiana:

Nie moge wykonywać każdej pracy, która chce, muszę wybierać, które dam radę wykonać, ograniczam ilość pracy, nie mogę zbyt często wyjeżdżać, a chciałabym więcej szkoleń zaliczyć, pracodawca nie rozumie, że czasem po lekach dzień jest ,wyjęty z życia".

[Co stanowi problem w podejmowaniu pracy?] Pobyty w szpitalu, kontrole w poradni, niezrozumienie pracodawcy, a także obawa pracodawcy przed częstymi pobytami na zwolnieniu lekarskim.

[Co stanowi problem w podejmowaniu pracy?] Nieakceptowanie przez pracodawce ograniczeń, jakie niesie ze soba choroba; mała świadomość pracodawców o tego typu schorzeniach; traktowanie osób chorych jako niepetnoprawnych pracowników.

[Potrzeba] więcej empatii od strony pracodawcy. My sobie tej choroby nie wybraliśmy, też nie jest nam z nia tatwo.

Ciekawym wątkiem podniesionym przez respondentów są relacje osób chorych ze współpracownikami. Chorzy mają poczucie konieczności negocjowania wynikających ze schorzenia warunków swojej aktywności nie tylko z pracodawcą, lecz czasem także z innymi pracownikami, którzy postrzegają ich jako osoby wymigujące się od pracy czy nadużywające zwolnień lekarskich:

Częste nieobecności w pracy, co może spowodować również „zawiść” wspótpracowników, jak i postrzeganie osoby chorej przez pracodawce jako osobę mato wydajna lub taka, na której nie można polegać.

[...] powinno być duże uświadamianie pracodawców, ale i społeczeństwa. By na przyklad pracujac kolezanki i koledzy z pracy nie mieli postawy typu... ,ta to tylko stale L4, nie za dobrze ci" itp.

U mnie choroby nie widać, więc większość uważa, że udaję.

W kontekście relacji pracownik - pracodawca podkreślić jednak należy również świadomość części badanych, że z punktu widzenia pracodawcy zatrudnianie osoby cierpiącej na przewlekłą chorobę nie zawsze może być najkorzystniejszym rozwiązaniem. 
Pracownicy chorzy sa mniej wydajni i mniej atrakcyjni dla pracodawców i to jest normalne, żadne sztuczne regulacje tego nie zmienia... Choroba ta jest ciężka i szczególnie pracownicy fizyczni odczuja jej skutki.

W przywołanej tu wypowiedzi osoba deprecjonuje znaczenie dodatkowych mechanizmów wspierających popyt na osoby chore na rynku pracy. Większość jednak z osób, które dostrzegały konieczność systemowych zmian w tym obszarze, wskazywała na potrzebę wspierania tych przedsiębiorców, którzy zatrudniają osoby chore:

Brak ofert pracy zdalnej, z której da się godnie żyć, brak ofert pracy na pół etatu, brak dofinansowania takich etatów przez państwo.

Systemowe zmiany proponowane przez respondentów dotyczyły zarówno skali szerszej, związanej na przykład z przepisami prawnymi oraz zasadami orzecznictwa o niepełnosprawności, jak i kwestii związanych z praktycznym wymiarem dnia pracy.

ZUS. Bo gdy tylko chory człowiek chce dorobić chociaż na część etatu do renty, to na komisji ZUS zabiera rentę. A sorry, ale będac chorym nie da się wyżyć za połowe etatu. A na caly etat większość rencistów nie ma zdrowia. Więc ludzie wola nie podejmować pracy.

Ból stawów kręgostupa i rąk, który uniemożliwia mi pracę, ale wedtug ZUS nie jestem niezdolna do pracy.

ZUS nie daje na te choroby renty, więc i brak środków do życia.

Brak dobrego systemu. Mogę na przykład pracować 2 godziny, potem muszę się położyć na pół godziny. I tak w kółko. Wykluczam prace fizyczne, bo nie dam już rady.

Brak elastyczności godzin pracy.

Część osób sygnalizowała psychologiczny problem z akceptacją finansowej zależności od innych, co może pogłębiać niskie poczucie wartości i wzmacniać syndrom wykluczenia społecznego. Niemożność podjęcia pracy w takich sytuacjach może uruchamiać całą lawinę problemów, które wzajemnie się na siebie nakładając dodatkowo obciążają chorego:

Trudności ze znalezieniem pracy, a co za tym idzie — mało pieniędzy na leczenie, które jest zwyczajnie drogie. A co za tym idzie - nie dość, że brak samodzielności $w$ radzeniu sobie $w$ codziennym życiu, to jeszcze zależność finansowa od innych.

Niemożność podjęcia pracy w oczywisty sposób rzutuje także — wskutek braków zasobów finansowych — na charakter leczenia czy intensywność rehabilitacji. „Problem z pracą, a co z tym się wiąże — brak pieniążków” wpływa 
nie tylko na jakość życia, poczucie własnej wartości, możliwość samorealizacji czy nawiązywania społecznych relacji — lecz także najbardziej bezpośrednio staje się wyzwaniem w obliczu choroby i konieczności opłacenia (mniej lub bardziej oczywistych) kosztów związanych z leczeniem.

Jedną z prób podejmowanych przez osoby niemające możliwości wykonywania dotychczasowego bądź wyuczonego zawodu ze względu na chorobę jest zmiana profesji. Mając świadomość własnych ograniczeń ruchowych bądź związanych z trybem pracy, część badanych podjęła decyzje o przekwalifikowaniu się w celu znalezienia zatrudnienia będącego do pogodzenia $\mathrm{z}$ dolegliwością zdrowotną. Ujawniony w badaniu odsetek osób, które podjęły takie działania, jest wysoki - aż 41,12\% (139 osób) potwierdziło zmianę pracy ze względu na chorobę, natomiast 38,17\% (129 badanych) stwierdziło, że choroba nie wpłynęła na ich miejsce pracy. Dość wysoki odsetek respondentów wybrał odpowiedź „trudno powiedzieć/nie dotyczy” (19,82\% - 67 osób), co może świadczyć o dokonaniu wynikających z choroby pewnych przeobrażeń w obszarze pracy, jednak nie na tyle znaczących (np. zmiana czasu pracy), by można było określać je mianem przekwalifikowania się (wykres 6).

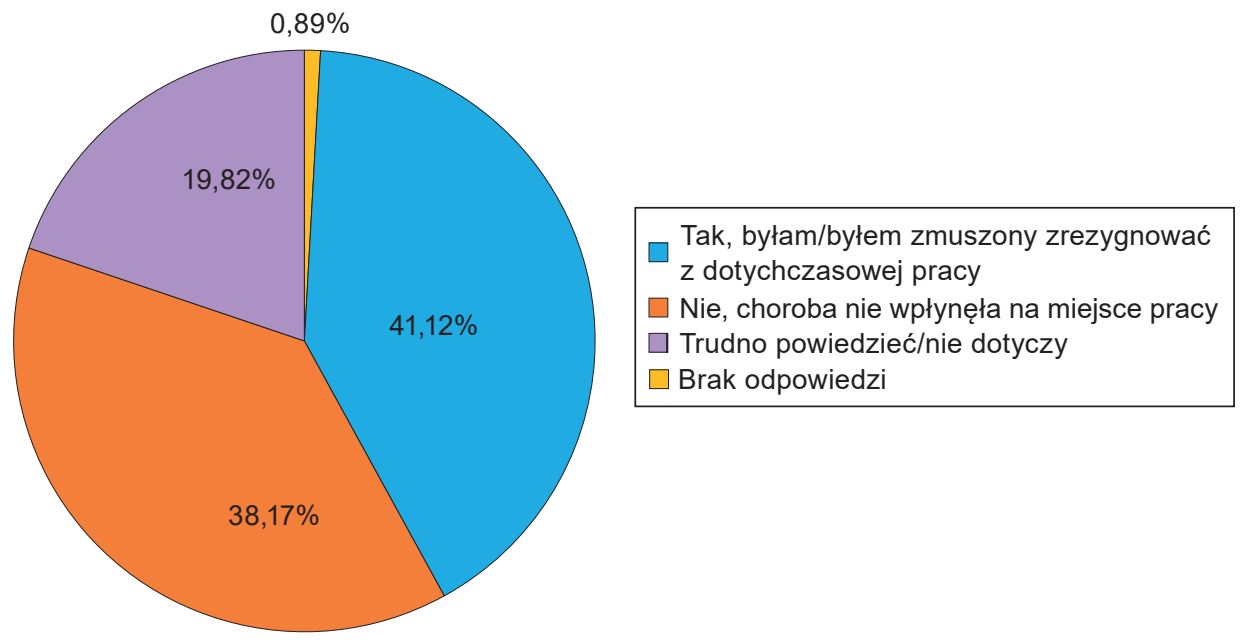

Wykres 6. Odsetek badanych, którzy przekwalifikowali się ze względu na swoją chorobę $(\mathrm{n}=338)$

Ankietowanych respondentów zapytano także o ich odczucia względem marginalizacji lub wykluczenia na rynku pracy. Uzyskane odpowiedzi potwierdzają wskazane wcześniej problemy z funkcjonowaniem osoby chorej na rynku pracy. Największa część badanych potwierdziła takie odczucia (43,49\% - 147 osób), nie czuje się wykluczonymi lub zmarginalizowanymi na rynku pracy zaledwie $34,02 \%$ badanych (115 osób). Ponad $1 / 5$ badanych - 21,89\% (74 osoby) — wybrała odpowiedź „trudno powiedzieć” (wykres 7). Taki rozkład odpowiedzi jest ważnym wskaźnikiem postrzegania swojej pozycji na rynku pracy przez chorych, świadectwem ich poczucia mniejszych szans i gorszych warunków w porównaniu z pozostałą częścią populacji. 


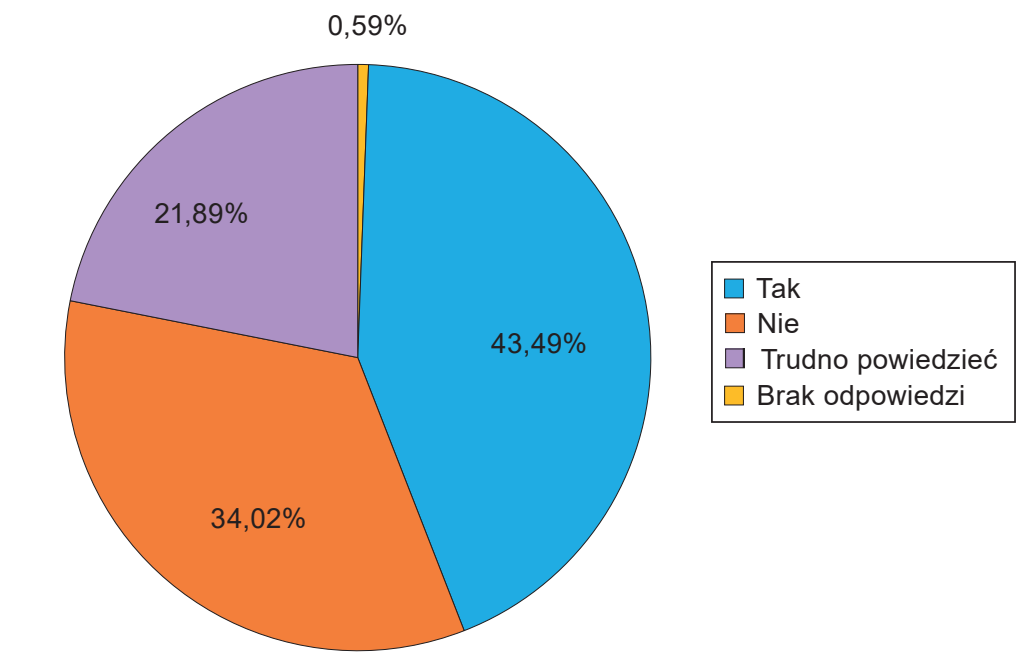

Wykres 7. Poczucie wykluczenia na rynku pracy $(\mathrm{n}=338)$

\section{Podsumowanie}

Zreferowane badania miały na celu analizę poziomu aktywności osób cierpiących na choroby reumatyczne oraz identyfikację podstawowych barier w jej podejmowaniu. W badaniu wzięło udział 338 osób, co uznać należy za wystarczająco dużą grupę respondentów, która zagwarantowała wysoki poziom rzetelności otrzymanych wyników. Biorące udział w badaniu osoby były w bardzo zróżnicowanym wieku i zamieszkiwały w miejscowościach różnej wielkości. Ograniczeniem próby badawczej była natomiast nadreprezentacja w niej kobiet.

Co niezwykle istotne, grupa badanych była mocno zróżnicowana również ze względu na czas trwania choroby, co stworzyło możliwość uchwycenia kontekstów i konsekwencji choroby $\mathrm{z}$ wielu perspektyw. Badani to przede wszystkim osoby cierpiące na reumatoidalne zapalenie stawów (RZS), zesztywniające zapalenie stawów kręgosłupa (ZZSK), toczeń rumieniowaty układowy (TRU) i fibromialgię. Większość z nich nie posiadała orzeczenia o stopniu niepełnosprawności - ale jednocześnie $\mathrm{w}$ próbie reprezentowane były osoby z różnym stopniem niepełnosprawności (znacznym, umiarkowanym, lekkim).

Zdecydowaną większość badanych stanowiły osoby pracujące zawodowo, w tym ponad połowa ankietowanych w pełnym wymiarze etatu. Przeważająca część respondentów miała przekonanie, że choroba komplikuje życie zawodowe, a ponad $1 / 3$ z nich uznała łączenie pracy zawodowej z chorobą za niezwykle trudne. Wśród przyczyn wymieniano przede wszystkim ograniczenia związane z bólem i zmęczeniem, ale także nieprzewidywalność choroby (i w konsekwencji ograniczoną dyspozycyjność). Podkreślano problemy w relacjach z pracodawcami 
i współpracownikami, którzy często nie wykazują zrozumienia względem chorych, zwracano też uwagę na kwestie systemowe, wynikające z polskiego prawa.

Wielu cierpiących na choroby reumatyczne podejmuje próby modyfikacji swojego życia zawodowego i dostosowania go do nowych, narzucanych przez chorobę warunków poprzez przekwalifikowanie się. Prawie połowa badanych miała poczucie wykluczenia lub marginalizacji na rynku pracy.

Uzyskane wyniki badań stanowić mogą świadectwo z jednej strony — fundamentalnego znaczenia pracy zawodowej dla rozwoju człowieka i jego subiektywnego poczucia jakości życia, z drugiej zaś — olbrzymiej determinacji cierpiących na dokuczliwe schorzenia reumatyczne osób w podejmowaniu zawodowej aktywności. Rozpoznanie ich sytuacji powinno być priorytetowym krokiem w projektowaniu odpowiednich programów przeciwdziałających ich wykluczeniu zawodowemu, którego doświadczenie badani potwierdzali w wypowiedziach. Rozwój elastycznych form zatrudnienia i rosnące znaczenie pracy zdalnej winny być rodzajem wsparcia w poszukiwaniu właściwych dla osób cierpiących na choroby przewlekłe formuł pracy. Ich aktywizacja zawodowa jest ważna nie tylko dla nich samych, lecz także ma doniosłe (również ekonomiczne) znaczenie dla polityki społecznej państwa. W poszukiwaniu dobrych rozwiązań nie wolno zapominać o kluczowej kwestii - czyli samych chorych i ich potrzebach, czego przejawem powinny być badania ewaluujące projektowane i implementowane rozwiązania.

\section{Bibliografia}

Bergoglio J.M., Skórka A., 2013: Wniebie i na ziemi. Przeł. M. Szafrańska-Brandt. Kraków: Znak.

Daca A., Bryl E., 2013: Toczeń rumieniowaty układowy - kryteria diagnostyczne i kliniczne skale oceny aktywności choroby - rys historyczny. „Forum Medycyny Rodzinnej”, nr 7(5), s. 225-243.

Garbat M., 2013: Aktywizacja zawodowa osób z niepetnosprawnościa - bariery i koszty. Zielona Góra: Uniwersytet Zielonogórski.

Idasiak-Piechocka I., Perkowska-Ptasińska A., 2016: Toczeń rumieniowaty układowy (TRU). „Nefrologia i Dializoterapia Polska”, nr 2(20), s. 93-99.

Kołczewska A., 2004: Leczenie czynnikami biologicznymi chorych na zesztywniajace zapalenie stawów kręgostupa. „Terapia”, nr 5(152), z. 2.

Kubicka M., 2012: Młodzi z niepetnosprawnościa na rynku pracy. W: H. Liberska, A. Malina, D. Suwalska-Barancewicz, red.: Funkcjonowanie współczesnych młodych ludzi w zmieniajacym się świecie. Warszawa: Wydawnictwo Difin.

Kwiatkowska B., Raciborski F., Maślińska M., Kłak A., Gryglewicz J., Samel-Kowolik P., 2014: Wczesna diagnostyka chorób reumatycznych, ocena obecnej sytuacji i rekomendacje zmian. Warszawa: Instytut Reumatologii w Warszawie.

Ossowski R., 1991: Teoretyczne i praktyczne podstawy rehabilitacji. Bydgoszcz: WUWSP w Bydgoszczy. 
Smoleńska Ż., Zdrojewski Z., 2010: Odmienności w przebiegu chorób reumatycznych u osób w podeszłym wieku. „Gerontologia Polska”, nr 4(18), s. 169-175.

Stanisławska-Biernat E., 2015: Zesztywniajace zapalenie stawów kręgostupa. W: Eadem: Poradnik dla pacjentów. Zesztywniajace zapalenie stawów kręgostupa. UCB/VEDIM dostępne online: https://www.ucb.pl/_up/ucb_pl/documents/Zesztyw niajace\%20Zapalenie\%20Stawow\%20Kregoslupa_Poradnik\%20dla\%20Pacjentow. pdf [dostęp: 11.01.2018].

Sulima R., 2015: Pracowitość. W: M. Bogunia-Browska, red.: Fundamenty dobrego spoteczeństwa. Wartości. Kraków: Znak.

Szczepańska M., Muszewska E., Szprynger K., Niwińska-Faryna B., 2008: Toczeń rumieniowaty układowy a ciąża. „Wiadomości Lekarskie”, T. 61, s. 4-6.

Tłustochowicz W., 2014: Recenzje raportu i projektu zmian. W: B. Kwiatkowska, F. Raciborski, M. Maślińska, A. Kłak, J. Gryglewicz, P. Samel-Kowolik, red.: Wczesna diagnostyka chorób reumatycznych, ocena obecnej sytuacji i rekomendacje zmian. Warszawa: Instytut Reumatologii w Warszawie.

Wiland P., 2012: Czy jesteśmy w stanie wcześniej rozpoznawać zesztywniajace zapalenie stawów kręgostupa? „Postępy Nauk Medycznych”, T. 25, nr 2, s. 115-119.

Wisłowska M., Kanecki K., Tyszko P., Kapała A., 2010: Jakość życia zależna od zdrowia u pacjentów z reumatoidalnym zapaleniem stawów. „Reumatologia”, $\mathrm{nr} 48$, s. $104-111$.

Wytrążek M., Huber J., Zagłoba-Kaszuba A., Kulczyk A., Lipiec J., 2009: Neurofizjologiczne aspekty bólu mięśniowo-powięziowego. „Nowiny Lekarskie”, nr 78 (2), s. $153-158$. 